\title{
Limnological assessment of the meteo-hydrological and physicochemical factors for summer cyanobacterial blooms in a regulated river system
}

\author{
Dong-Gyun Hong ${ }^{1}$, Dong-Kyun Kim${ }^{2}$, Hyun-Woo Kim ${ }^{3}$, Yuno Do ${ }^{1}$, Hak Young Lee ${ }^{4}$ and \\ Gea-Jae Joo ${ }^{1 *}$ \\ 1 Department of Biological Sciences, Pusan National University, Busan 609-735, Republic of Korea \\ 2 Department of Physical and Environmental Sciences, University of Toronto, Toronto, Ontario M1C1A4, Canada \\ 3 Department of Environmental Education, Sunchon National University, Suncheon, Jeonnam 504-742, Republic of Korea \\ ${ }^{4}$ Department of Biological Science, Chonnam National University, Gwangju 500-757, Republic of Korea
}

Received 4 May 2015; Accepted 9 December 2015

\begin{abstract}
This study aimed to explain how the changes in certain hydrological, meteorological and physicochemical factors influence the cell density of the cyanobacteria Microcystis aeruginosa in the Nakdong River. Occurrence patterns of $M$. aeruginosa were analyzed between 1993 and $2010(N=96)$ using a selforganizing map. The cell density of $M$. aeruginosa was sensitive to certain meteorological, hydrological and physicochemical factors. In addition, our clustering analysis results identified specific limnological features under different environmental conditions. Cluster 1 suggested that high rainfall and increased river flow, dam discharge, total phosphorous and phosphate concentrations were associated with low M. aeruginosa cell density (June-July; monsoon season). However, cluster 2 suggested low irradiance since water temperature decreases with irradiation time, and thus low M. aeruginosa cell density (April-June and after November). Finally, cluster 3 was indicative of high water temperature and irradiance, increased irradiation time, low phosphate and nitrate concentrations, and high $M$. aeruginosa cell density (August, after the monsoon season). Taken together, these results suggest that rainfall, river flow, water temperature and nutrient concentration (i.e., phosphates and nitrates) were the primary factors that affected cyanobacterial bloom occurrence in the Nakdong River. M. aeruginosa blooms can be suppressed by employing an integrated water resource management program that accommodates meteo-hydrological factors along with the effective control of exogenous nutrient sources.
\end{abstract}

Key words: Cyanobacterial bloom / Microcystis aeruginosa / rainfall / regulated river / self-organizing map

\section{Introduction}

Cyanobacterial blooms are a type of severe harmful algal bloom that are associated with global environmental problems, including water toxicity, odor, and excessive cell degradation. These blooms result in hypoxic conditions and toxicity, leading to the death of fish, birds and animals, thereby adversely affecting natural ecosystems and human society (Prescott, 1948; Tencalla et al., 1994; de Figueiredo et al., 2006; Graham et al., 2010). The freshwater systems in Northeast Asia also experience similar problems. The summer monsoon is a major climate phenomenon in Northeast Asia that brings abundant rainfall to East China, Japan and Korea (Yihui and Chan,

\footnotetext{
*Corresponding author: gjjoo@pusan.ac.kr
}

2005). Summer cyanobacterial blooms in this region frequently occur when the water levels are stable and nutrient input is high (Ha et al., 2002; Hong et al., 2002; Joung et al., 2011). Lake Taihu in China (Duan et al., 2012; Zhang et al., 2012), Lakes Suwa (Yokoyama and Park, 2002) and Kasumigaura (Islam et al., 2012) in Japan, and Han and Nakdong Rivers and Daechung Reservoir in South Korea are representatives of cyanobacterial bloom ecosystems. The Nakdong River is a regulated river system with dams and an estuarine barrage for water resource management during the monsoon season (Jeong et al., 2011; Kim et al., 2012; Hong et al., 2014). This river had a severe cyanobacterial bloom problem in the 1990s (Ha et al., 1998, 1999).

Most rainfall in the Nakdong River basin falls during the monsoon period (the monsoon is called "Jangma" in 
Korean) and varies between 783 and $1829 \mathrm{~mm}$ [approximately $60-65 \%$ of the total annual rainfall; data from the Korean Meteorological Administration (KMA) obtained between 1961 and 2014], thereby affecting river flow and total dam discharge. After the summer monsoon, the physicochemical environment (i.e., high water temperature, $\mathrm{pH}$ and nutrient enrichment) of the Nakdong River becomes favorable for cyanobacterial bloom development (Ha et al., 1998, 1999). Previous studies have shown significant relationships between cyanobacterial blooms and monsoon rainfall (Jeong et al., 2003a, 2003b; Kim et al., 2007). Most studies on cyanobacterial blooms in the Nakdong River have focused on the severe cyanobacterial bloom of the 1990s (Jeong et al., 2003a; Kim et al., 2007). Owing to adequate rainfall and water quality improvements, these blooms diminished in the 2000s (Chun et al., 1999; Lee et al., 2010), but have reappeared in the last 5 years. The hydrological changes and rainfall variability in the Nakdong River due to global climate change have been hypothesized to promote cyanobacterial bloom outbreaks (Seo et al., 2012; Hur et al., 2013). For almost 20 years, long-term ecological research (LTER) data have provided considerably more complex and variable information about the Nakdong River (Jeong et al., 2011; Kim et al., 2012; Hong et al., 2014), and comparison of cyanobacterial bloom trends based on LTER data combined with monsoon climate data (e.g., summer monsoon rainfall) might lead to the identification of more complex inter-annual variability of bloom formation.

In the Nakdong River, cyanobacteria dominate the phytoplankton assemblage in summer (i.e., June to early September). In this study, we (i) analyzed the causal relationship patterns between Microcystis aeruginosa Kützing and various meteorological, hydrological and physicochemical factors using a self-organizing map (SOM); (ii) investigated the major factors that characterize cyanobacterial blooms; and (iii) discussed potential strategies to control M. aeruginosa.

\section{Material and methods}

\section{Study site}

The Nakdong River is the second largest river in South Korea (approximately $525 \mathrm{~km}$ ). The basin has an average annual rainfall of approximately $1200 \mathrm{~mm}$, of which $60 \%$ occurs in the summer (June-September) (Kim et al., 2002). Ten million people use the Nakdong River for industrial and agricultural purposes and for drinking water. Thus, it is of considerable importance to the regional community. The Nakdong River is a regulated river controlled by four dams (Andong, Imha, Hapcheon and Namgang) and an estuarine barrage. Since the 1990s, cyanobacterial blooms have occurred frequently at the study site. The dominant cyanobacterial species is $M$. aeruginosa, but other genera such as Oscillatoria and Anabaena have also been detected.

The study site, located at Mulgeum, is $28 \mathrm{~km}$ north of the mouth of the Nakdong River and is also the primary water source for nearly 5 million inhabitants of Busan in South Korea (Fig. 1). Eutrophication at Mulgeum has accelerated due to nutrient input from upstream tributaries, and the estuarine barrage has increased water retention times for the lower river. Therefore, cyanobacterial blooms were observed at the lower Nakdong River at Mulgeum when summer rainfall is below the average (Kim et al., 2011).

\section{Data collection}

The study site was monitored weekly or biweekly from 1993 to 2010, during which time 96 cases of $M$. aeruginosa occurrence were recorded. The hydrological factors investigated were river flow and total dam discharge; these data were obtained from the Korean Water Management Information System (http://www.wamis.go.kr). The total dam discharge was the sum of the discharge from the four large dams; river flow was measured at Jindong station, located approximately $50 \mathrm{~km}$ upstream from the study site.

Meteorological factors (i.e., number of days without rainfall, irradiation time and rainfall amount) were obtained from the KMA (http://www.kma.go.kr). Data for the specific factors were summed at different time intervals -2 weeks (i.e., total rainfall, irradiation and irradiation time), 1 week (i.e., number of days without rainfall) and per day (i.e., dam discharge and river flow) in association with the limnological sampling dates.

Physicochemical characteristics were assessed by measuring water temperature, dissolved oxygen (YSI 85; YSI Inc., Yellow Springs, OH, USA), pH (Orion 3-Star pH meter; Thermo Fisher Scientific Inc., Beverly, MA, USA) and conductivity (YSI 30; YSI, Yellow Springs, OH, USA). Turbidity (Micro100 Laboratory Turbidimeter; HF Scientific, Fort Myers, FL, USA), alkalinity, chlorophyll- $a$ content and nutrient concentration (i.e., total nitrogen [TN], total phosphorous [TP], nitrate, phosphate and silica) were calculated according to Wetzel and Likens (1991). Samples of M. aeruginosa were collected and immediately preserved in Lugol's solution. The number of $M$. aeruginosa cells were counted using an inverted microscope (Zeiss, Telaval 31, Jena, Germany) at $400 \times$ magnification using the sedimentation method (Utermöhl, 1958).

\section{SOM}

Artificial neural networks (ANNs) are known to be powerful processors that can be used to extract information by incorporating adaptive and self-organizing properties (Haykin and Lippmann, 1994). They have been widely used to determine an optimal solution using a datalearning process. SOM, also known as unsupervised ANN, recognizes a certain pattern from multi-dimensional data and maps it onto the reduced dimensional space that commonly shapes a two-dimensional plane (Kohonen, 


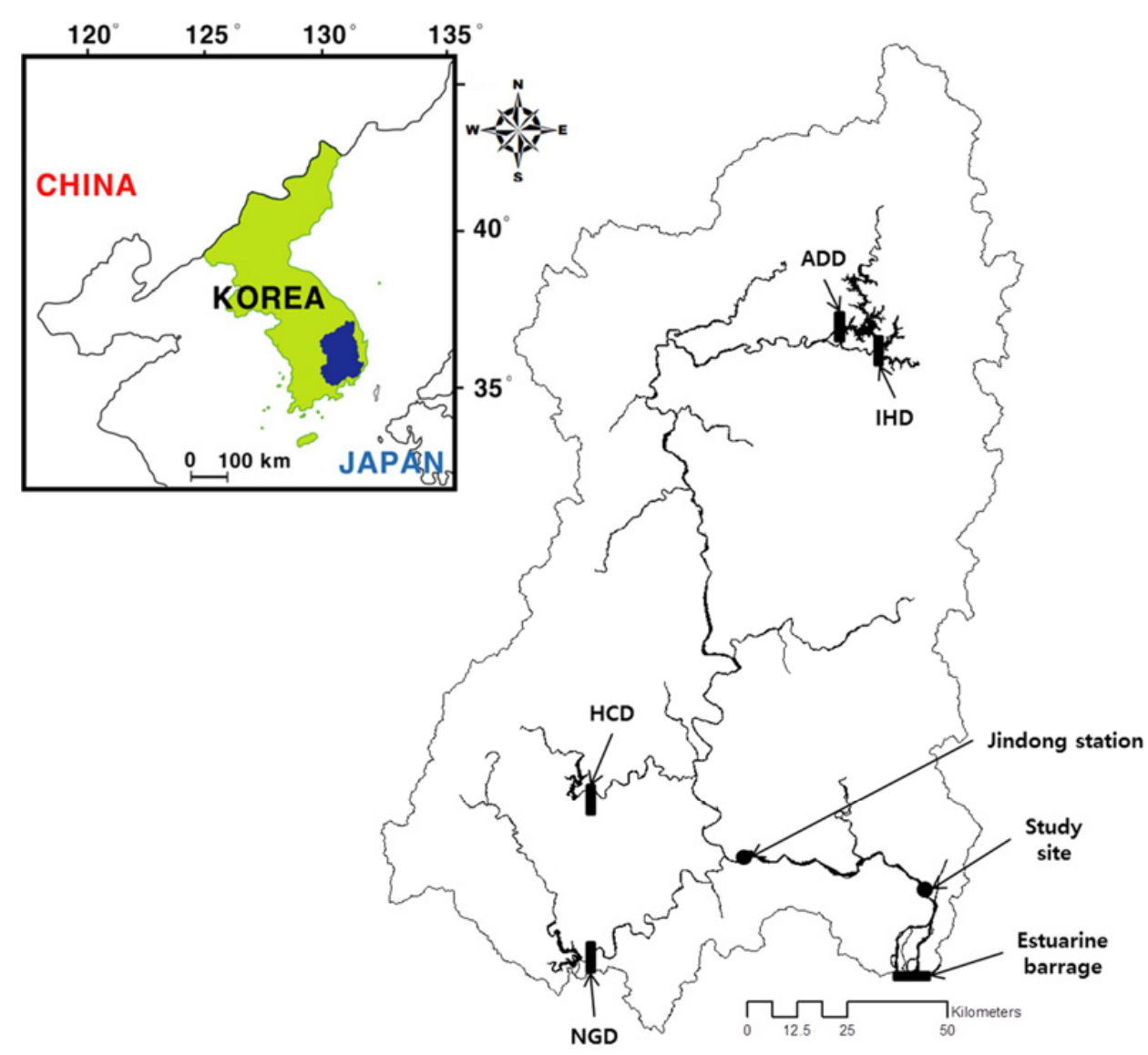

Fig. 1. Map of the Nakdong River basin (rectangles indicate dam locations; ADD, Andong dam; IHD, Imha dam; HCD, Hapcheon dam; NGD, Namgang dam; Jindong station: river flow measure station).

1997). In ecological research, SOM is often considered as a more appropriate multivariate analysis than other conventional approaches such as statistical methods under the linear assumption, since the competitive principle of the SOM network can be more feasible for dealing with the nonlinearity of ecological data (Giraudel and Lek, 2001). Therefore, SOM has been extensively used in pattern recognition in various ecological domains, including benthic macroinvertebrates in running waters (Chon et al., 2000; Park et al., 2003), zooplankton communities (Kim et al., 2012) and biomanipulation assessments (Ha et al., 2014).

SOM basically consists of two layers: (i) an input layer associated with sample units of input variables $\left(x_{1}, x_{2}, \ldots\right.$, $x_{k}$; where $k$ is the number of input variables) and (ii) an output layer in which virtual units of the dataset are arranged (denoted as $m_{l}$ in Fig. 2). Each virtual unit contains the corresponding weight vector $w_{i}$, connecting the input and output. Once the dataset is trained, the inputs seek the best/winning neuron, also known as the best matching unit (BMU). The mathematical equation describing this process is as follows:

$$
\left\|x-w_{c}\right\|=\min _{i}\left\{\left\|x-w_{i}\right\|\right\}
$$

where $x$ denotes the input, and $w_{c}$ is the BMU in the input space among $i$ numbers of weight vectors. The $w_{i}$ is initially generated at random and gradually converges over time. During the training process, the neurons activate each other to learn something from the same input. Furthermore, each weight vector mimics a biological property of adaptation by updating itself at each iteration $t$. All the neurons are iteratively updated by their neighboring neurons. The process can be expressed as follows:

$$
w_{i}^{(t+1)}=w_{i}^{(t)}+\alpha^{(t)}\left[x_{i}^{(t)}-w_{i}^{(t)}\right] Z_{i}
$$

where $\alpha$ is the learning rate, and $Z_{i}$ is the neighborhood function; both converge to zero over time. After training, all the weight vectors are conserved in a hexagonal-lattice map called a $U$-matrix. Data ordination is then delineated based on the correspondence between inputs and the $U$-matrix.

The SOM was trained with 20 input variables, including four meteorological, two hydrological and 13 physicochemical factors, as well as $M$. aeruginosa data collected from 1993 to $2010 \quad(N=96)$. Before training, all the input variables were selectively transformed using the logarithmic scale. For example, several input variables, including $M$. aeruginosa cell density, turbidity, chlorophyll- $a$, TN, TP, nitrate, phosphate and silica, were log-transformed to determine their distributional normality. The SOM size was determined 

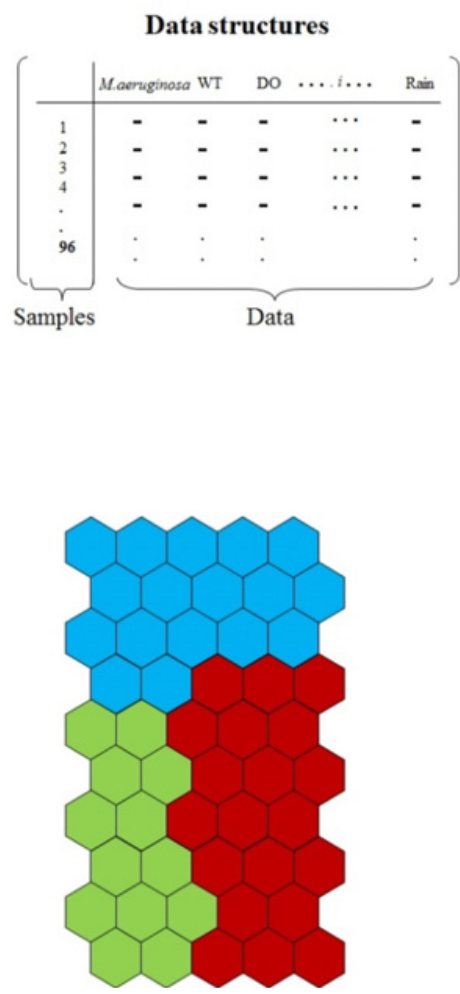

Fig. 2. Basic concept of the self-organizing map.

on the basis of the number adjacent to $5 \times \sqrt{n}$ (Vesanto and Alhoniemi, 2000). The final SOM was selected based on the minimum quantization and topographic errors as previously used by Uriarte and Diaz (2006) and Céréghino and Park (2009). To cluster the SOM map, the SOM units were classified into groups based on the dendrogram of a hierarchical cluster analysis performed using Ward's linkage method by using the Euclidian distance (Park et al., 2014). The SOM model was developed using MATLAB 6.1 (The MathWorks Inc., Natick, MA, USA) and the SOM Toolbox (Helsinki University of Technology, Helsinki).

\section{Statistical analysis}

The effect of the different variables on the SOM results was compared using analysis of variance and Scheffe's test for mean separation. Pearson's correlation was used to compare the relationship between the cell density of $M$. aeruginosa and each variable in each cluster. Before correlation analysis was performed, data for cell density, turbidity, chlorophyll- $a$, TN, TP, nitrate, phosphate and silica were log-transformed (Zar, 1996), whereas the remaining variables were not transformed and represented the primary data values. The analyses were conducted using SPSS Version 21 (IBM Corporation, Armonk, NY, USA).

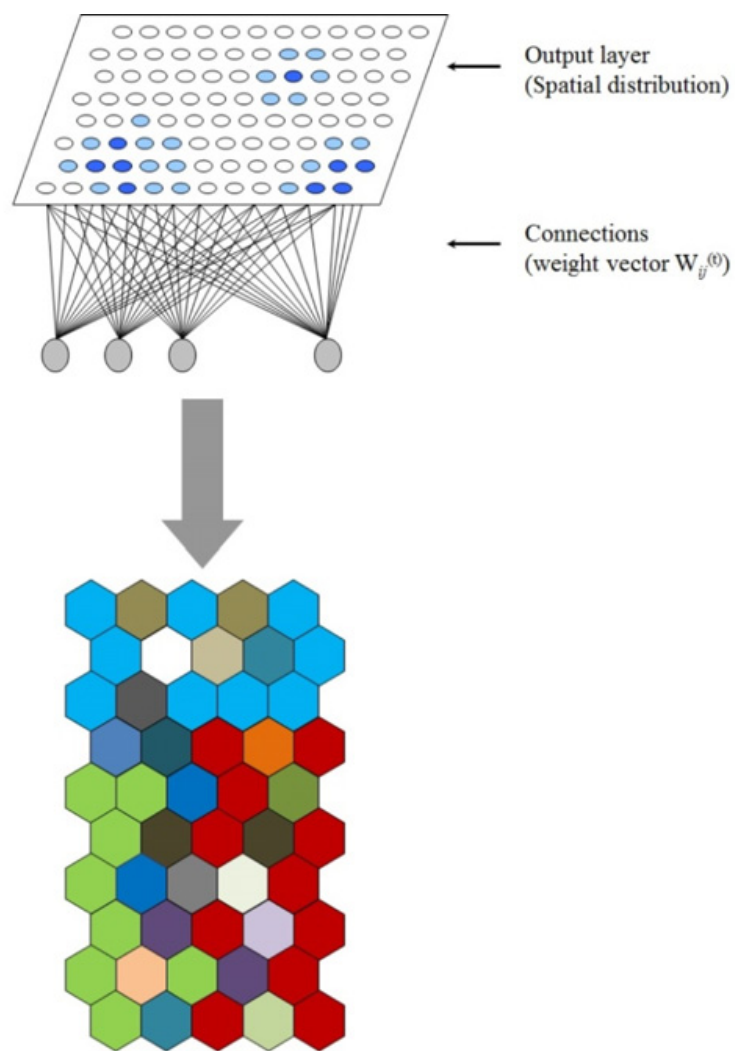

\section{Results}

\section{Temporal trends of phytoplankton along with precipitation}

Distinct inter-annual variations in $M$. aeruginosa, chlorophyll- $a$ and rainfall were observed (Fig. 3). M. aeruginosa appeared every year from 1993 to 2001, and a large peak in $M$. aeruginosa cell density was recorded from 1994 to 1997. Subsequently, M. aeruginosa was not observed between 2002 and 2008, but appeared again from 2008 to 2010. The average chlorophyll- $a$ concentration was generally stable, but increased from 1993 to 2001. During the study period (from April to November), the average annual rainfall was $1131 \mathrm{~mm}$. In the years with limited rainfall, the density of $M$. aeruginosa cells was often above 50000 cells $\mathrm{mL}^{-1}$. In general, rainfall affected the density of $M$. aeruginosa cells and chlorophyll- $a$ concentration (Fig. 3).

\section{Pattern of variables on the SOM}

The SOM plane was optimized on a $10 \times 5$ size map and the topology was more smoothly trained (quantization error: 0.557, topographic error: 0.000) (Fig. 4). The relationship between different environmental variables and $M$. aeruginosa cell density was investigated (Fig. 5).

In the component plane, higher water temperature was associated with higher $M$. aeruginosa cell density, whereas 

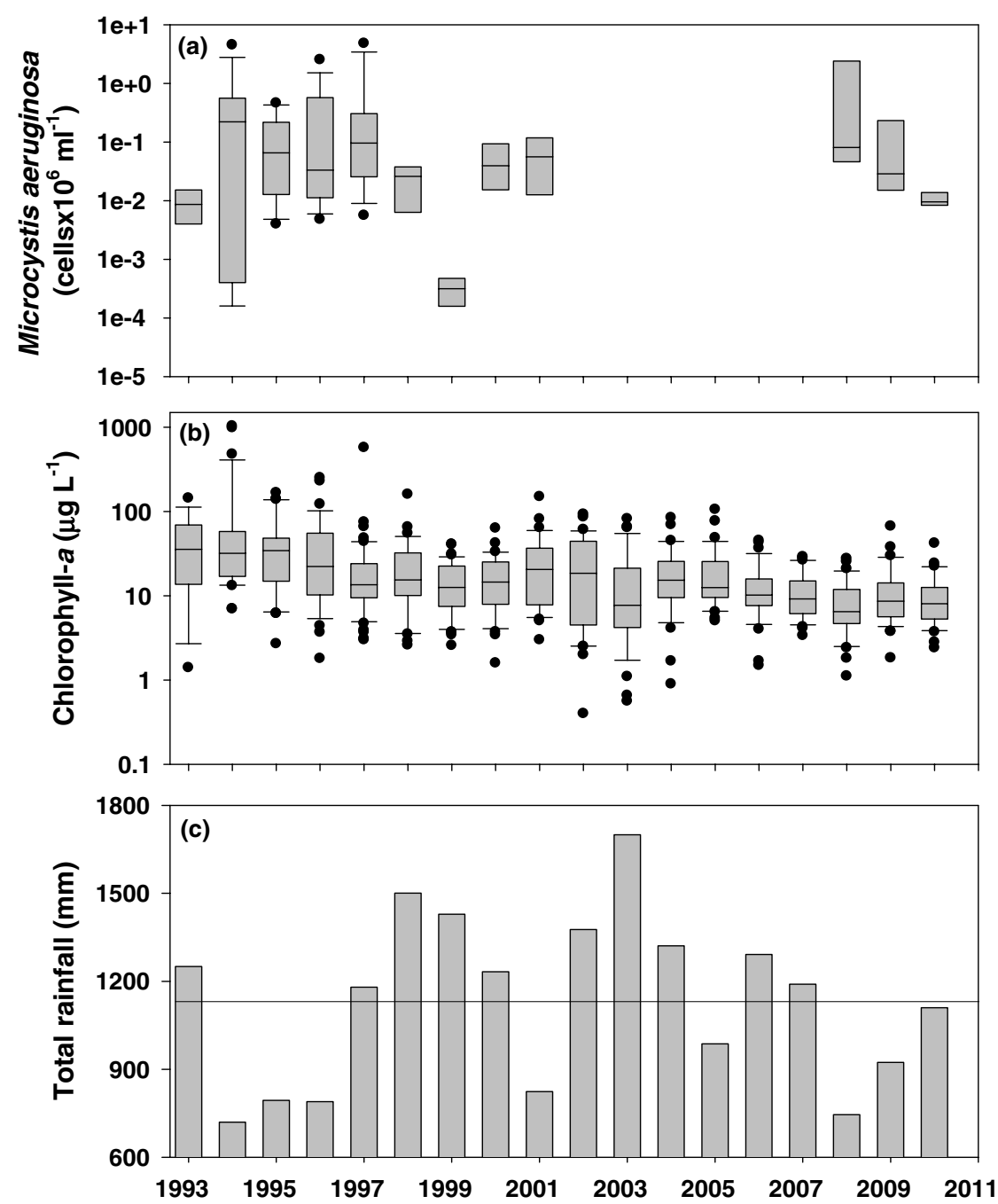

Fig. 3. Annual patterns of Microcystis aeruginosa, chlorophyll-a, and rainfall between April and November 1993-2010: (a) $M$. aeruginosa cell density, (b) chlorophyll- $a$ concentration. Boxes indicate the data range; lines within boxes indicate the mean; whiskers indicate the standard deviation; dots represent outliers; (c) total rainfall; the solid line indicates an annual average of $1131 \mathrm{~mm}$.

lower water temperature and $M$. aeruginosa cell density occupied the left-bottom area. Dissolved oxygen was associated with phytoplankton biomass and water temperature. Higher concentrations of dissolved oxygen were found in two sections of the component plane. In the rightbottom corner of the plane, a higher concentration of dissolved oxygen was associated with higher $M$. aeruginosa cell density, indicating that oxygen increased with an increase in M. aeruginosa photosynthetic output.

In the left-bottom corner of the plane, the increase in dissolved oxygen appeared to have a stronger correlation with lower water temperature than with phytoplankton-associated photosynthesis, whereas lower water temperature was indicative of a higher dissolved oxygen concentration. The highest (i.e., most basic) $\mathrm{pH}$ was found in the right-bottom section of the plane.

Conductivity and alkalinity patterns were homogenous but not strongly correlated with $M$. aeruginosa cell density. Higher turbidity was located in two zones of the component plane. The right-top area largely coincided with increasing rainfall, which caused an increase in suspended solids. The right-bottom area mostly coincided with increasing $M$. aeruginosa cell density. The area of increased chlorophyll- $a$ concentration overlapped with the increased density of $M$. aeruginosa cells. The left-bottom area was occupied by higher chlorophyll- $a$ concentration but a lower density of M. aeruginosa cells.

Concentrations of TN and nitrate had similar distributions on the component map, except in the area of maximum cell density. The left-bottom area had significantly lower TN and nitrate concentrations. The input of TP and phosphate into the river matched with the rainfall pattern; therefore, these factors increased during the rainy season (Ha et al., 2002). Different correlation patterns were confirmed between the maximum cell density of $M$. aeruginosa and $\mathrm{TP}$ and phosphate in the right and left-bottom zones, respectively. No difference occurred in the concentration of TP between the left-bottom and right-bottom areas, whereas the concentration of 

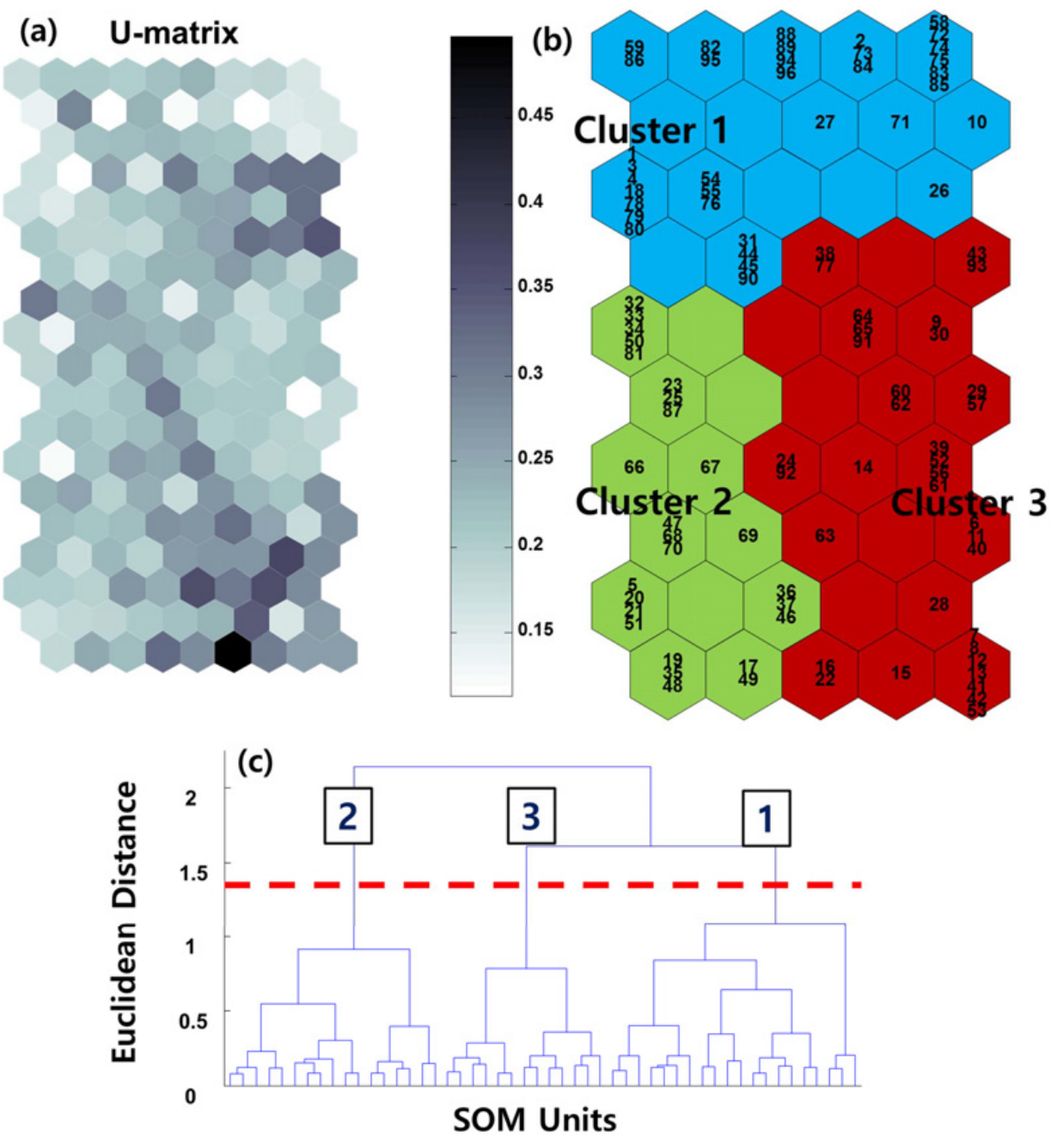

Fig. 4. Clustering results of the self-organizing map (SOM): (a) $U$-matrix (gray scale bar: distance between neurons); (b) data ordination; and (c) dendrogram. Numbers within cells indicate data samples used for modeling.

phosphate was lower in the right-bottom area than in the left-bottom area.

The concentration pattern of silica coincided with the rainfall pattern, but not with $M$. aeruginosa cell density. The area of low water temperature and silica concentration overlapped with low $M$. aeruginosa cell density, whereas chlorophyll- $a$ concentration was slightly higher than that at the same level in the other areas.

$M$. aeruginosa cell density was lower on the top section of the component map, where rainfall, dam discharge, and river flow were significantly higher. During the summer rainy season, rainfall, dam discharge, and river flow increased. The irradiance level and irradiating time showed similar patterns to $M$. aeruginosa cell density, although cell density was more strongly correlated with irradiating time than irradiance in the area with highest cell density.

\section{SOM clustering and its characteristics}

As explained by the Euclidean distance, cluster 2 was divided first, and then was subdivided by clusters 1 and 3
(Fig. 4 (c)). Statistically significant differences among cluster variables were shown in Table 1 . The densities of $M$. aeruginosa cells were significantly similar for clusters 1 and 2, but not for cluster 3. Water temperature, conductivity, silica, irradiating time and total dam discharge were significantly different among the clusters. The number of $M$. aeruginosa occurrence was different between each cluster (Table 2).

The results of correlation analysis for each cluster showed clear differences in the effect of variables on $M$. aeruginosa cell density. Water temperature had the largest positive correlation with $M$. aeruginosa cell density in clusters 1 and 3, whereas the concentration of TP had the largest negative correlation with $M$. aeruginosa cell density in cluster 2 (Table 3 and Appendices 1-4).

In cluster 1 , the density of $M$. aeruginosa cells was only $3.5 \%$ lower than that in cluster 3. River flow, total dam discharge, and rainfall were higher in cluster 1 than in the other clusters (Table 1). M. aeruginosa appeared in all years in cluster 1, with the highest incidence in summer from July to August (Table 3). M. aeruginosa cell density increased with increasing water temperature. 

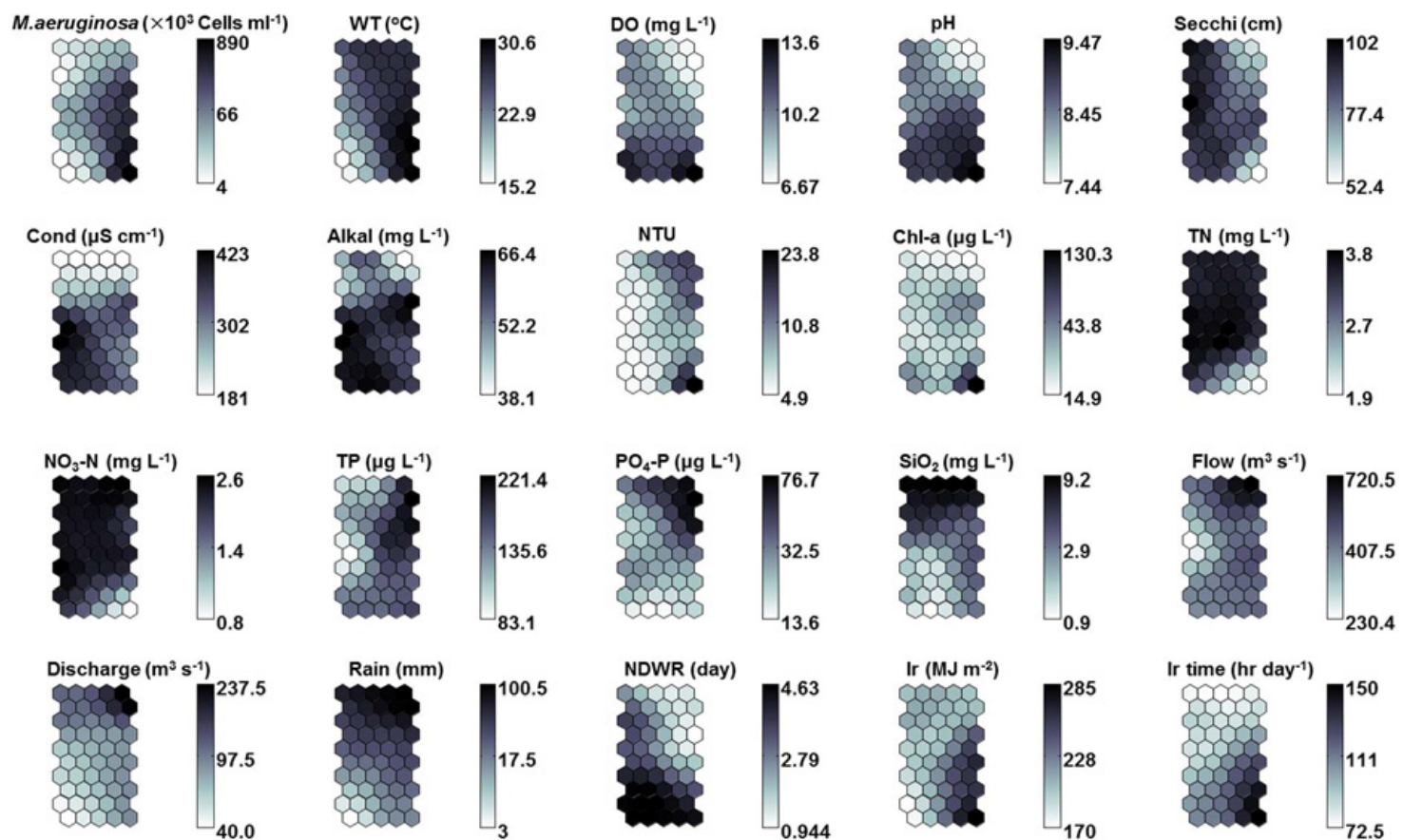

Fig. 5. Component maps of Microcystis aeruginosa and the corresponding meteorological, hydrological and physicochemical variables. The three numbers next to each band indicate the range of the variables. All acronyms are defined in Table 1.

Table 1. Comparison of variables (mean $\pm \mathrm{SE}$ ) for different clusters defined in the self-organizing map (SOM).

\begin{tabular}{|c|c|c|c|c|c|c|}
\hline \multirow[b]{2}{*}{ Variable } & \multirow[b]{2}{*}{ Acronym } & \multirow[b]{2}{*}{ Unit } & \multicolumn{3}{|c|}{ Clusters } & \multirow[b]{2}{*}{ Total $(n=96)$} \\
\hline & & & $1(n=35)$ & $2(n=26)$ & $3(n=35)$ & \\
\hline M. aeruginosa & M. aeruginosa & Cells.mL ${ }^{-1}$ & $32106 \pm 4634^{a}$ & $31159 \pm 3325^{\mathrm{a}}$ & $897423 \pm 138365^{b}$ & $347330 \pm 93805$ \\
\hline Water temperature & WT & ${ }^{\circ} \mathrm{C}$ & $25.9 \pm 0.4^{\mathrm{b}}$ & $18.8 \pm 0.5^{\mathrm{a}}$ & $28.8 \pm 0.3^{c}$ & $25.0 \pm 0.6$ \\
\hline Dissolved oxygen & $\mathrm{DO}$ & mg. $\mathrm{L}^{-1}$ & $8.8 \pm 0.2^{\mathrm{a}}$ & $10.7 \pm 0.3^{\mathrm{b}}$ & $10.7 \pm 0.3^{\mathrm{b}}$ & $10.0 \pm 0.3$ \\
\hline $\mathrm{pH}$ & $\mathrm{pH}$ & - & $8.0 \pm 0.1^{\mathrm{a}}$ & $8.7 \pm 0.1^{b}$ & $9.0 \pm 0.1^{b}$ & $8.5 \pm 0.1$ \\
\hline Secchi depth & Secchi & $\mathrm{cm}$ & $81.0 \pm 2.9^{\mathrm{ab}}$ & $95.8 \pm 3.3^{b}$ & $72.7 \pm 2.3^{\mathrm{a}}$ & $82.0 \pm 3.0$ \\
\hline Conductivity & Cond & $\mu \mathrm{S} . \mathrm{cm}^{-1}$ & $199.3 \pm 3.8^{\mathrm{a}}$ & $401.5 \pm 8.4^{c}$ & $322.5 \pm 7.2^{\mathrm{b}}$ & $299.0 \pm 10.6$ \\
\hline Alkalinity & Alkal & $\mathrm{mg} . \mathrm{L}^{-1}$ & $45.5 \pm 1.7^{\mathrm{a}}$ & $66.4 \pm 1.0^{b}$ & $59.9 \pm 1.3^{\mathrm{b}}$ & $56.4 \pm 1.6$ \\
\hline Turbidity & NTU & NTU & $10.7 \pm 0.9^{\mathrm{ab}}$ & $5.1 \pm 0.2^{\mathrm{a}}$ & $16.3 \pm 1.6^{b}$ & $11.2 \pm 1.2$ \\
\hline Chlorophyll- $a$ & Chl- $a$ & $\mu \mathrm{g} . \mathrm{L}^{-1}$ & $22.6 \pm 1.4^{\mathrm{a}}$ & $33.3 \pm 2.7^{\mathrm{ab}}$ & $111.1 \pm 20.5^{b}$ & $57.8 \pm 13.2$ \\
\hline Total nitrogen & $\mathrm{TN}$ & mg. $\mathrm{L}^{-1}$ & $3.4 \pm 0.1^{\mathrm{a}}$ & $3.4 \pm 0.1^{\mathrm{a}}$ & $3.1 \pm 0.1^{\mathrm{a}}$ & $3.3 \pm 0.1$ \\
\hline Nitrate & $\mathrm{NO}_{3}-\mathrm{N}$ & mg. $\mathrm{L}^{-1}$ & $2.5 \pm 0.1^{\mathrm{b}}$ & $2.4 \pm 0.1^{\mathrm{ab}}$ & $1.9 \pm 0.1^{\mathrm{a}}$ & $2.2 \pm 0.1$ \\
\hline Total phosphorus & $\mathrm{TP}$ & $\mu \mathrm{g} . \mathrm{L}^{-1}$ & $166.9 \pm 13.1^{\mathrm{ab}}$ & $122.3 \pm 5.4^{\mathrm{a}}$ & $186.0 \pm 9.3^{b}$ & $161.8 \pm 10.4$ \\
\hline Phosphate & $\mathrm{PO}_{4}-\mathrm{P}$ & $\mu \mathrm{g} . \mathrm{L}^{-1}$ & $50.4 \pm 3.5^{\mathrm{a}}$ & $28.4 \pm 2.3^{\mathrm{a}}$ & $39.0 \pm 5.0^{\mathrm{a}}$ & $40.3 \pm 4.0$ \\
\hline Silica & $\mathrm{SiO}_{2}$ & mg. $\mathrm{L}^{-1}$ & $8.5 \pm 0.3^{b}$ & $2.5 \pm 0.2^{\mathrm{a}}$ & $3.9 \pm 0.3^{\mathrm{a}}$ & $5.2 \pm 0.4$ \\
\hline Irradiance & $\mathrm{Ir}$ & MJ.m ${ }^{-2}$ & $203.4 \pm 3.3^{\mathrm{a}}$ & $186.8 \pm 4.6^{\mathrm{a}}$ & $254.8 \pm 4.7^{b}$ & $217.6 \pm 5.2$ \\
\hline Irradiating time & Ir time & h.day ${ }^{-1}$ & $79.6 \pm 2.2^{\mathrm{a}}$ & $99.0 \pm 2.1^{\mathrm{b}}$ & $124.4 \pm 2.7^{\mathrm{c}}$ & $101.2 \pm 3.1$ \\
\hline River flow & Flow & $\mathrm{m}^{3} \cdot \mathrm{s}^{-1}$ & $561.4 \pm 29.7^{b}$ & $347.1 \pm 12.8^{\mathrm{a}}$ & $480.4 \pm 30.5^{\mathrm{ab}}$ & $473.8 \pm 28.0$ \\
\hline Dam discharge & Discharge & $\mathrm{m}^{3} \cdot \mathrm{s}^{-1}$ & $179.6 \pm 21.2^{b}$ & $51.9 \pm 1.9^{\mathrm{a}}$ & $86.3 \pm 3.9^{\mathrm{a}}$ & $111.0 \pm 14.1$ \\
\hline Rainfall & Rain & $\mathrm{mm}$ & $82.5 \pm 4.2^{b}$ & $16.0 \pm 1.5^{\mathrm{a}}$ & $31.0 \pm 2.5^{\mathrm{a}}$ & $45.7 \pm 4.2$ \\
\hline Number of days without rainfall & NDWR & Day & $2.3 \pm 0.2^{\mathrm{a}}$ & $4.1 \pm 0.1^{b}$ & $2.9 \pm 0.2^{\mathrm{a}}$ & $3.0 \pm 0.2$ \\
\hline
\end{tabular}

Values in bold are the greatest among the clusters within each variable. Mean \pm SE values within columns followed by different lowercase letters are significantly different (Scheffe's test; $P<0.05$ ).

However, this increase was accompanied by a decrease in dissolved oxygen and $\mathrm{pH}$. An average $\mathrm{pH}$ of 8.0 is optimal for $M$. aeruginosa growth (Shapiro, 1984). The density of $M$. aeruginosa cells increased with an increase in river flow. Therefore, increases in water temperature can be associated with increases in $M$. aeruginosa cell density following the rainy season (Table 3, Appendix 2).
In cluster 2, the cell density of $M$. aeruginosa was similar to that in cluster 1 . Total dam discharge and river flow were lower than those in the other clusters. The mean number of days $\pm \mathrm{SE}$ without rainfall in cluster 2 was $4.1 \pm 0.1$ days, which was higher than those in other clusters. Water temperature in cluster 2 was $18.8 \pm 0.5^{\circ} \mathrm{C}$, which was the lowest among the three clusters (Table 1). 
Table 2. Number of Microcystis aeruginosa outbreaks observed in each cluster by year and month.

\begin{tabular}{|c|c|c|c|c|c|}
\hline & \multicolumn{3}{|c|}{ Clusters } & \multirow[b]{2}{*}{ Total } \\
\hline & & 1 & 2 & $\overline{3}$ & \\
\hline \multirow[t]{12}{*}{ Year } & 1993 & 4 & 1 & & 5 \\
\hline & 1994 & 2 & 4 & 10 & 16 \\
\hline & 1995 & 3 & 6 & 5 & 14 \\
\hline & 1996 & 2 & 8 & 6 & 16 \\
\hline & 1997 & 4 & 5 & 10 & 19 \\
\hline & 1998 & 6 & & 1 & 7 \\
\hline & 1999 & 3 & & & 3 \\
\hline & 2000 & 5 & 1 & & 6 \\
\hline & 2001 & 3 & 1 & 2 & 6 \\
\hline & 2008 & & & 1 & 1 \\
\hline & 2009 & 2 & & & 2 \\
\hline & 2010 & 1 & & & 1 \\
\hline \multirow[t]{8}{*}{ Month } & 4 & 3 & & & 3 \\
\hline & 5 & & 3 & 1 & 4 \\
\hline & 6 & 1 & 2 & 3 & 6 \\
\hline & 7 & 11 & 1 & 6 & 18 \\
\hline & 8 & 12 & & 16 & 28 \\
\hline & 9 & 7 & 5 & 9 & 21 \\
\hline & 10 & 1 & 9 & & 10 \\
\hline & 11 & & 6 & & 6 \\
\hline
\end{tabular}

Table 3. Pearson's correlation coefficients between Microcystis aeruginosa and the 19 meteo-hydrological and physicochemical variables.

\begin{tabular}{|c|c|c|c|c|}
\hline \multirow[b]{2}{*}{ Variable } & \multicolumn{3}{|c|}{ Clusters } & \multirow[b]{2}{*}{ Total } \\
\hline & 1 & 2 & 3 & \\
\hline Water temperature & $0.727 * *$ & $0.417^{*}$ & $0.620 * *$ & $0.646^{* *}$ \\
\hline Dissolved oxygen & $-0.437 * *$ & -0.350 & 0.225 & 0.025 \\
\hline $\mathrm{pH}$ & $-0.443 * *$ & -0.382 & 0.182 & 0.164 \\
\hline Secchi depth & -0.047 & 0.305 & -0.205 & -0.145 \\
\hline Conductivity & 0.118 & 0.335 & -0.068 & 0.171 \\
\hline Alkalinity & 0.219 & -0.094 & 0.199 & 0.199 \\
\hline Turbidity $^{a}$ & 0.028 & -0.174 & $0.420 *$ & $0.368 * *$ \\
\hline Chlorophyll- $a^{\text {a }}$ & -0.089 & $-0.422 *$ & 0.278 & $0.245^{*}$ \\
\hline Total nitrogen ${ }^{\mathrm{a}}$ & -0.290 & 0.301 & -0.153 & -0.191 \\
\hline Nitrate $^{\mathrm{a}}$ & -0.284 & 0.172 & -0.060 & $-0.289 *$ \\
\hline Total phosphorus ${ }^{\mathrm{a}}$ & 0.136 & $-0.601 * *$ & 0.244 & 0.160 \\
\hline Phosphate $^{\mathrm{a}}$ & 0.189 & -0.011 & 0.136 & 0.047 \\
\hline Silica $^{\mathrm{a}}$ & -0.001 & 0.107 & 0.145 & -0.040 \\
\hline Irradiance & -0.087 & 0.249 & $0.416^{*}$ & $0.509 *$ \\
\hline Irradiating time & -0.012 & -0.121 & $0.473 * *$ & $0.483 * *$ \\
\hline River flow ${ }^{\mathrm{a}}$ & $0.439 * *$ & -0.373 & 0.018 & 0.073 \\
\hline Dam discharge $^{a}$ & 0.161 & 0.373 & $0.412 *$ & 0.120 \\
\hline Rainfall $^{\mathrm{a}}$ & 0.115 & 0.223 & -0.115 & 0.016 \\
\hline Number of days without rainfall & -0.201 & -0.072 & 0.069 & -0.080 \\
\hline
\end{tabular}

Values in bold are the greatest among the variables within each cluster ( ${ }^{\text {a }}$ : natural log-transformed variable, $* P<0.05, * * P<0.01$ )

M. aeruginosa appeared from 1994 to 1998 and in 2000 to 2001, which coincided with periods of low rainfall. During the years with low rainfall, $M$. aeruginosa appeared in early summer from May to July, and in fall from September to November (Table 2). In cluster 2, the TP concentration decreased with an increase in $M$. aeruginosa cell density; however, in the other clusters, increases in TP concentration were followed by an increase in $M$. aeruginosa cell density (Table 3, Appendix 3).

In cluster 3, M. aeruginosa cell density (897423 \pm 138365 cells $\left.\mathrm{mL}^{-1}\right)$ and water temperature $\left(28.8 \pm 0.3^{\circ} \mathrm{C}\right)$ and $\mathrm{pH}(9.0 \pm 0.1)$ were the highest among the three clusters. Irradiance, irradiating time, turbidity, chlorophyll- $a$ and TP concentration were higher in cluster 3 than in the other clusters (Table 1). In cluster 3, M. aeruginosa appeared between 1994 and 1998, in 2001, and in 2008. Further, M. aeruginosa blooms were found in summer (i.e., August from 1994 to 1998; Table 2). Irradiance had a stronger correlation with cell density than with irradiating time in all the clusters, whereas irradiating time showed a stronger correlation with cell density than with irradiance in cluster 3 (Table 3, Appendix 4). 


\section{Discussion}

\section{What causes the M. aeruginosa bloom?}

Increased river flow suppressed $M$. aeruginosa cell density in the Nakdong River, because most cyanobacteria do not bloom in areas with short water retention times (Jeong et al., 2011, 2003a). Alternatively, low rainfall was responsible for an increase in the water retention time, thereby increasing $M$. aeruginosa cell density by establishing environmental conditions optimal for its growth (Joo and Jeong, 2005).

Our SOM results corroborated Shapiro's hypothesis (1990) that cyanobacteria dominate in rivers and lakes because of their adaptability to water temperatures, light, the $\mathrm{N}: \mathrm{P}$ ratio, $\mathrm{CO}_{2}$ concentrations and $\mathrm{pH}$. M. aeruginosa have gas vacuoles that enable them to remain at the water surface layer, which is advantageous in utilizing $\mathrm{CO}_{2}$. This typically occurs when the $\mathrm{pH}$ increases after extensive photosynthesis occurs (Shapiro, 1984). In cluster 3, high water temperatures caused by strong irradiance (which is proportional to irradiating time) and a high $\mathrm{pH}$ might have provided a competitive advantage to the cyanobacterial bloom. The buoyancy of $M$. aeruginosa colonies creates scum, resulting in increased turbidity and low light penetration (i.e., Secchi depth).

With an increase in M. aeruginosa cell density (i.e., comparing cluster 3 with clusters 1 and 2), the concentrations of TP and phosphate increased, but TN and nitrate concentrations decreased. M. aeruginosa cannot fix nitrogen (Moisander et al., 2009) and obtains it from the surrounding water. The high level of nitrogen in the river promotes the growth of $M$. aeruginosa and increases the probability of blooms (McCarthy et al., 2009). In cluster 2, the TP concentration decreased as $M$. aeruginosa cell density increased; however, in the other clusters, increases in the TP concentration were followed by an increase in $M$. aeruginosa cell density. Because $M$. aeruginosa absorbs and stores phosphorous in the cells from water, its concentration decreases as rainfall decreases (e.g., cluster 2). $M$. aeruginosa cell density increased with an increase in water temperature, a pattern similar to that observed in the other clusters. Relatively low concentrations of phosphate in cluster 3 were associated with a higher phosphate uptake, which increases the growth rate of M. aeruginosa (Xie et al., 2003; Reynolds, 2006; Chuai et al., 2011).

\section{Interaction between $M$. aeruginosa and meteo-hydrological factors in the Nakdong River}

In contrast to previous $M$. aeruginosa studies at the Nakdong River, a clear inter-annual variation of species proliferation was observed in this study. During a prolonged period of low rainfall during the mid-1990s, $M$. aeruginosa bloomed intensely in the Nakdong basin (Ha et al., 2002; Park et al., 2002; Jeong et al., 2003a). However, M. aeruginosa failed to bloom at the study site in the early 2000s, although several studies reported a very low abundance in the Nakdong River (Son, 2013a, 2013b). In 2008, the number of $M$. aeruginosa cells exceeded $4000000 \mathrm{~mL}^{-1}$. Although the amount of rainfall in 2001 and 2005 was below the 18-year average, M. aeruginosa blooms were not detected. Short-term studies revealed seasonality in cyanobacterial blooms (i.e., based on water temperature and irradiance), although LTER recognized that inter-annual rainfall variability by global climate change is an important cause of $M$. aeruginosa blooms (Paerl and Huisman, 2009; Paerl and Paul, 2012). If the amount of rainfall across two or three consecutive years is large enough to raise the water level at the study site, then $M$. aeruginosa blooms can be suppressed (Jeong et al., 2007).

The hydrological changes at Nakdong River (i.e., drought and flooding) are important factors in temperate river-floodplain ecosystems, especially for phytoplankton (Mihaljević and Stević, 2011). This is true in Northeast Asia where summer rainfall is the major water source for residents. Our findings suggested that $M$. aeruginosa blooms were strongly associated with water temperature and nutrient concentration, but the distribution of annual rainfall patterns governs the inter-annual variation of $M$. aeruginosa populations. Pollution control in the Nakdong River's basin is known to be a key factor for suppressing cyanobacterial blooms. In contrast, understanding the inter-annual variability of cyanobacterial blooms, with respect to long-term rainfall patterns, might help in the management of water quality. The relationship between cyanobacterial blooms and hydrological characteristics was successfully identified in our study by application of SOM to a long-term M. aeruginosa database.

\section{Water quality management strategies in a regulated river}

Since the 1990s, the Korean government has implemented strategies to reduce cyanobacterial blooms in order to improve the water quality of the Nakdong River. These methods include installment of wastewater treatment facilities and pollution management (Chun et al., 1999; Jung et al., 2008; Lee et al., 2010). These efforts were then applied to other major rivers in Korea, and eventually, the Korean government initiated the Total Maximum Daily Load program. As a result, biochemical oxygen demand and TP concentration have decreased in the major rivers. Reduced TP concentrations are related to decreased cyanobacterial blooms (Stumpf et al., 2012). However, unlike in other countries, effluent standards in Korea remain high. The TP effluent standard for wastewater treatment in Korea is $2.0-8.0 \mathrm{mg} . \mathrm{L}^{-1}$ and, in the US, it is $0.3-1.0 \mathrm{mg} . \mathrm{L}^{-1}$ (according to the US Environmental Protection Agency). In addition, the newly established TP effluent standard in Japan is $1.0-3.0 \mathrm{mg} \cdot \mathrm{L}^{-1}$. Therefore, further reduction of the occurrence of cyanobacterial blooms requires the use of two-fold lower TP effluent standard because the present 
TP effluence determines the main influx of $\mathrm{P}$ in the rivers of Korea.

In this study, cyanobacterial blooms were confirmed to be associated with the summer monsoon in Korea: they were suppressed during the summer monsoon period (from July to August) and recurred after the monsoon (from August to September). In regulated river systems, dams and estuarine barrages control river flow. Therefore, a regulated river system can control cyanobacterial blooms by regulating river flow via hydrological control devices. In particular, summer cyanobacterial blooms could be reduced or eliminated by increasing the total dam discharge, which in turn, decreases water retention time and increases water velocity. This scenario has been achieved in the Australian Darling River, where cyanobacterial cell density decreased from 100000 to 1000 cells. $\mathrm{mL}^{-1}$ in a week when $3000 \mathrm{~mL}$.day ${ }^{-1}$ of water was discharged (Mitrovic et al., 2011). In the Nakdong River, if the total dam discharge increases over 129 CMS (a $50 \%$ increase in dam discharge from cluster 3), cyanobacterial blooms would be suppressed after the monsoon and the hot summer period (from August to September). The dam-weir-estuarine barrage system needs to be considered in order to create an integrated, regulated river plan, which has been defined by previous smart-flow strategies applied in other countries and in Korea.

As mentioned above, cyanobacterial blooms were found to be associated with the summer monsoon in Korea: they were suppressed during the summer monsoon period (from July to August) and recurred after the monsoon (from August to November). In a regulated river system, successful water resource management requires the simultaneous control of pollution levels and river flow. Pollution control is focused on point pollution; however, measures to reduce non-point pollution, such as the control of farming and livestock, are also important. In regulated river flow, water source security for reducing cyanobacterial blooms is a major factor during the summer monsoon. Hence, the control of cyanobacterial blooms involves many factors and the integration of watershed management and meteo-hydrological and physicochemical factors of regulated river systems. Reducing dam and weir discharge can reduce cyanobacterial blooms in the middle of rivers, but might result in the transport of cyanobacterial colonies from the middle to the shoreline or further downstream (Qin et al., 2010). Thus, an optimal flow rate, with respect to efficient cyanobacterial bloom regulation, needs to be determined.

The Four Major Rivers Restoration Project (FMRRP) was initiated in 2009 to prevent drought and flooding, increase water quality, provide leisure and enhance regional culture. It targeted the major rivers (i.e., the Han, Geum, Young san-Seomjin and Nakdong) in South Korea. The project required weir installation, dredging, widening portions of the river and maintaining the optimal water level, which were the major objectives of the \$19 billion project (Normile, 2010; Shin and Chung, 2011). The completion of the FMRRP led to a decrease in water velocity and increase in water retention times in the Nakdong River system. These hydrological changes led to cyanobacterial blooms in the river (Domingues et al., 2013). Previous management studies focused on the lower Nakdong River (from the river mouth to $30-40 \mathrm{~km}$ upstream); however, water management and models of cyanobacterial bloom prediction studies are presently needed for the mid-lower Nakdong River basin (Seo et al., 2012; Hur et al., 2013; Srivastava et al., 2015).

\section{Conclusion}

Meteorological, hydrological and physicochemical factors explained the presence of $M$. aeruginosa blooms based on SOM results for the regulated Nakdong River system. An increase in rainfall, river flow and dam discharge decreased cell density of $M$. aeruginosa. In contrast, low summer rainfall and increased water temperature, irradiance and irradiating time resulted in higher $M$. aeruginosa cell densities. In a regulated river system, increases in water retention time would increase the frequency of cyanobacterial blooms due to increases in water temperature and nutrient concentrations. Therefore, the successful control of cyanobacterial blooms requires integrated watershed management that accommodates the control and management of meteo-hydrological and physicochemical factors.

Acknowledgements. This work was supported by National Research Foundation of Korea (NRF) Grants funded by the Korea government (Grant No., NRF-2014M3C8A4030721).

\section{References}

Céréghino R. and Park Y.S., 2009. Review of the self-organizing map (SOM) approach in water resources: commentary. Environ. Model. Softw., 24, 945-947.

Chon T.S., Park Y.S. and Cha E.Y., 2000. Patterning of community changes in bentic macroinvertebrates collected from urbanized streams for the short term prediction by temporal artificial neuronal networks. In: Lek $\mathrm{S}$. and Guegan, J.F. (eds.), Artificial Neuronal Networks: Application to Ecology and Evolution, Springer, Berlin, 99-114.

Chuai X., Ding W., Chen X., Wang X., Miao A., Xi B., He L. and Yang L., 2011. Phosphorus release from cyanobacterial blooms in Meiliang Bay of Lake Taihu, China. Ecol. Eng., 37, 842-849.

Chun K.C., Chang R.W., Williams G.P., Chang Y.S., Tomasko D., LaGory K., Ditmars J., Chun H.D. and Lee B.K., 1999. Water quality issues in the Nakdong River Basin in the Republic of Korea. Environ. Eng. Policy, 2, 131-143.

de Figueiredo D., Reboleira A.S.P., Antunes S., Abrantes N., Azeiteiro U., Gonçalves F. and Pereira M., 2006. The effect of environmental parameters and cyanobacterial blooms on phytoplankton dynamics of a Portuguese temperate Lake. Hydrobiologia, 568, 145-157.

Domingues R.B., Barbosa A.B. and Galvão H.M., 2013. River damming leads to decreased phytoplankton biomass and 
disappearance of cyanobacteria blooms. Estuar. Coast. Shelf Sci, 136, 129-138.

Duan H., Ma R. and Hu C., 2012. Evaluation of remote sensing algorithms for cyanobacterial pigment retrievals during spring bloom formation in several lakes of East China. Remote Sens. Environ., 126, 126-135.

Giraudel J.L. and Lek S., 2001. A comparison of self-organizing map algorithm and some conventional statistical methods for ecological community ordination. Ecol. Model., 146, 329-339.

Graham J.L., Loftin K.A., Meyer M.T. and Ziegler A.C., 2010. Cyanotoxin mixtures and taste-and-odor compounds in cyanobacterial blooms from the Midwestern United States. Environ. Sci. Technol., 44, 7361-7368.

Ha J.-Y., Hanazato T., Chang K.-H., Jeong K.-S. and Kim D.-K., 2014. Assessment of the lake biomanipulation mediated by piscivorous rainbow trout and herbivorous daphnids using a self-organizing map: a case study in Lake Shirakaba, Japan. Ecol. Inform, 29, 182-191.

Ha K., Kim H.-W. and Joo G.-J., 1998. The phytoplankton succession in the lower part of hypertrophic Nakdong River (Mulgum), South Korea. Hydrobiologia, 369-370, 217-227.

Ha K., Cho E., Kim H. and Joo G., 1999. Microcystis bloom formation in the lower Nakdong River, South Korea: importance of hydrodynamics and nutrient loading. Mar. Freshw. Res., 50, 89-94.

Ha K., Jang M.-H. and Joo G.-J., 2002. Spatial and temporal dynamics of phytoplankton communities along a regulated river system, the Nakdong River, Korea. Hydrobiologia, 470, 235-245.

Haykin S. and Lippmann R., 1994. Neural networks, a comprehensive foundation. Int. J. Neural Syst., 5, 363-364.

Hong D.-G., Jeong K.-S., Kim D.-K. and Joo G.-J., 2014. Remedial strategy of algal proliferation in a regulated river system by integrated hydrological control: an evolutionary modelling framework. Mar. Freshw. Res., 65, 379-395.

Hong S.S., Bang S.-W., Kim Y.-O. and Han M.-S., 2002. Effects of rainfall on the hydrological conditions and phytoplankton community structure in the riverine zone of the pal'tang reservoir, Korea. J. Freshw. Ecol., 17, 507-520.

Hur M., Lee I., Tak B.-M., Lee H.J., Yu J.J., Cheon S.U. and Kim B.-S., 2013. Temporal shifts in cyanobacterial communities at different sites on the Nakdong River in Korea. Water Res., 47, 6973-6982.

Islam M.N., Kitazawa D. and Park H.D., 2012. Numerical modeling on toxin produced by predominant species of cyanobacteria within the ecosystem of Lake Kasumigaura, Japan. Proc. Environ. Sci., 13, 166-193.

Jeong K.-S., Kim D.-K., Whigham P. and Joo G.-J., 2003a. Modelling Microcystis aeruginosa bloom dynamics in the Nakdong River by means of evolutionary computation and statistical approach. Ecol. Model., 161, 67-78.

Jeong K.-S., Recknagel F. and Joo G.-J., 2003b. Prediction and elucidation of population dynamics of a blue-green Alga (Microcystis aeruginosa) and diatom (Stephanodiscus hantzschii) in the Nakdong River-Reservoir System (South Korea) by a recurrent artificial neural network. In: Recknagel F. (ed.), Ecological Informatics, Springer, Berlin, 196-213.
Jeong K.-S., Kim D.-K. and Joo G.-J., 2007. Delayed influence of dam storage and discharge on the determination of seasonal proliferations of Microcystis aeruginosa and Stephanodiscus hantzschii in a regulated river system of the lower Nakdong River (South Korea). Water Res., 41, 1269-1279.

Jeong K.-S., Kim D.-K., Shin H.-S., Yoon J.-D., Kim H.-W. and Joo G.-J., 2011. Impact of summer rainfall on the seasonal water quality variation (chlorophyll a) in the regulated Nakdong River. KSCE J. Civ. Eng., 15, 983-994.

Joo G.J. and Jeong K.S., 2005. Modelling community changes of cyanobacteria in a flow regulated river (the lower Nakdong River, S. Korea) by means of a Self-Organizing Map (SOM). In: Lek S., Scardi M., Verdonschot P.M., Descy J.-P. and Park Y.-S. (eds.), Modelling Community Structure in Freshwater Ecosystems, Springer, Berlin, Heidelberg, 273-287.

Joung S.-H., Oh H.-M., Ko S.-R. and Ahn C.-Y., 2011. Correlations between environmental factors and toxic and non-toxic Microcystis dynamics during bloom in Daechung Reservoir, Korea. Harmful Algae, 10, 188-193.

Jung Y.J., Stenstrom M.K., Jung D.I., Kim L.H. and Min K.S., 2008. National pilot projects for management of diffuse pollution in Korea. Desalination, 226, 97-105.

Kim B.J., Kripalani R.H., Oh J.H. and Moon S.E., 2002. Summer monsoon rainfall patterns over South Korea and associated circulation features. Theor. Appl. Climatol., 72, 65-74.

Kim D.-K., Cao H., Jeong K.-S., Recknagel F. and Joo G.-J., 2007. Predictive function and rules for population dynamics of Microcystis aeruginosa in the regulated Nakdong River (South Korea), discovered by evolutionary algorithms. Ecol. Model., 203, 147-156.

Kim D.-K., Hong D.-G., Kim H.-W., Joo G.-J. and Jeong K.-S., 2011. Longitudinal patterns in limnological characteristics based on long-term ecological research in the Nakdong River. J. Ecol. Field Biol., 34, 39-47.

Kim D.-K., Jeong K.-S., Chang K.-H., La G.-H., Joo G.-J. and Kim H.-W., 2012. Patterning zooplankton communities in accordance with annual climatic conditions in a regulated river system (Nakdong River, South Korea). Int. Rev. Hydrobiol., 97, 55-72.

Kohonen T., 1997. Self-Organizing Maps, Springer, New York, $426 \mathrm{p}$.

Lee H.W., Bhang K.J. and Park S.S., 2010. Effective visualization for the spatiotemporal trend analysis of the water quality in the Nakdong River of Korea. Ecol. Inform., 5, 281-292.

McCarthy M., James R.T., Chen Y., East T. and Gardner W., 2009. Nutrient ratios and phytoplankton community structure in the large, shallow, eutrophic, subtropical Lakes Okeechobee (Florida, USA) and Taihu (China). Limnology, 10, 215-227.

Mihaljević M. and Stević F., 2011. Cyanobacterial blooms in a temperate river-floodplain ecosystem: the importance of hydrological extremes. Aquat. Ecol., 45, 335-349.

Mitrovic S.M., Hardwick L. and Dorani F., 2011. Use of flow management to mitigate cyanobacterial blooms in the Lower Darling River, Australia. J. Plankton Res., 33, 229-241.

Moisander P.H., Ochiai M. and Lincoff A., 2009. Nutrient limitation of Microcystis aeruginosa in northern 
California Klamath River reservoirs. Harmful Algae, 8, 889897.

Normile D., 2010. Restoration or devastation? Science, 327, 1568-1570.

Paerl H.W. and Huisman J., 2009. Climate change: a catalyst for global expansion of harmful cyanobacterial blooms. Environ. Microbiol. Rep., 1, 27-37.

Paerl H.W. and Paul V.J., 2012. Climate change: links to global expansion of harmful cyanobacteria. Water Res., 46, 1349 1363.

Park S.-B., Lee S.-K., Chang K.-H., Jeong K.-S. and Joo G.-J., 2002. The impact of monsoon rainfall (Changma) on the changes of water quality in the lower Nakdong River (Mulgeum). Korean J. Limnol., 35, 161-170.

Park Y.-S., Céréghino R., Compin A. and Lek S., 2003. Application of artificial neural networks for patterning and predicting aquatic insect species richness in running waters. Ecol. Model., 160, 165-280.

Park Y.-S., Kwon Y.-S., Hwang S.-J. and Park S., 2014. Characterizing effects of landscape and morphometric factors on water quality of reservoirs using a self-organizing map. Environ. Model. Softw., 55, 214-221.

Prescott G.W., 1948. Objectionable algae with reference to the killing of fish and other animals. Hydrobiologia, 1, $1-13$.

Qin B., Zhu G., Gao G., Zhang Y., Li W., Paerl H. and Carmichael W., 2010. A drinking water crisis in lake Taihu, China: linkage to climatic variability and lake management. Environ. Manage., 45, 105-112.

Reynolds C., 2006. Nutrient uptake and assimilation in phytoplankton. Ecol. Phytoplankton, 145-175.

Seo D., Kim M. and Ahn J.H., 2012. Prediction of chlorophyll-a changes due to weir constructions in the Nakdong River using EFDC-WASP modelling. Environ. Eng. Res., 17, 95-102.

Shapiro J., 1984. Blue-green dominance in lakes: the role and management significance of $\mathrm{pH}$ and $\mathrm{CO}_{2}$. Int. Rev. Ges. Hydrobiol. Hydrogr., 69, 765-780.

Shin J.-H. and Chung J.-Y., 2011. The four major rivers restoration project in South Korea. Proc. ICE-Civ. Eng. Thomas Telford, 164, 19-26.
Son H.-J., 2013a. Changes of dominant phytoplankton community in downstream of the Nakdong River: from 2002 to 2012. J. KSEE, 35, 289-293.

Son H.-J., 2013b. Long-term variations of phytoplankton biomass and water quality in the downstream of Nakdong River. J. KSEE, 35, 263-267.

Srivastava A., Ahn C.-Y., Asthana R.K., Lee H.-G. and Oh H.-M., 2015. Status, alert system, and prediction of cyanobacterial bloom in South Korea. BioMed Res. Int., 2015,8 .

Stumpf R.P., Wynne T.T., Baker D.B. and Fahnenstiel G.L., 2012. Interannual variability of cyanobacterial blooms in Lake Erie. PLoS ONE, 7, e42444.

Tencalla F.G., Dietrich D.R. and Schlatter C., 1994. Toxicity of Microcystis aeruginosa peptide toxin to yearling rainbow trout (Oncorhynchus mykiss). Aquat. Toxicol., 30, 215-224.

Uriarte E.A. and Diaz M.F., 2006. Topology preservation in SOM. Proc. World Acad. Sci., Eng. Technol., 15, 187-190.

Utermöhl H., 1958. Zur Vervollkommnung der quantitativen Phytoplankton-Methodik. Mitt. Int. Ver. Theor. Angew. Limnol., 9, 1-38.

Vesanto J. and Alhoniemi E., 2000. Clustering of the selforganizing map. IEEE Trans. Neural Netw. 11, 586-600.

Wetzel R.G. and Likens G.E., 1991. Limnological Analyses (2nd edn), Springer-Verlag, New York, 391 p.

Xie L., Xie P., Li S., Tang H. and Liu H., 2003. The low TN:TP ratio, a cause or a result of Microcystis blooms? Water Res., 37, 2073-2080.

Yihui D. and Chan J.C.L., 2005. The East Asian summer monsoon: an overview. Meteorol. Atmos. Phys., 89, 117-142.

Yokoyama A. and Park H.-D., 2002. Mechanism and prediction for contamination of freshwater bivalves (Unionidae) with the cyanobacterial toxin microcystin in hypereutrophic Lake Suwa, Japan. Environ. Toxicol., 17, 424-433.

Zar J.H., 1996. Biostatistical Analysis, Prentice-Hall, Inc., Upper Saddle River.

Zhang M., Duan H., Shi X., Yu Y. and Kong F., 2012. Contributions of meteorology to the phenology of cyanobacterial blooms: Implications for future climate change. Water Res., 46, 442-452. 

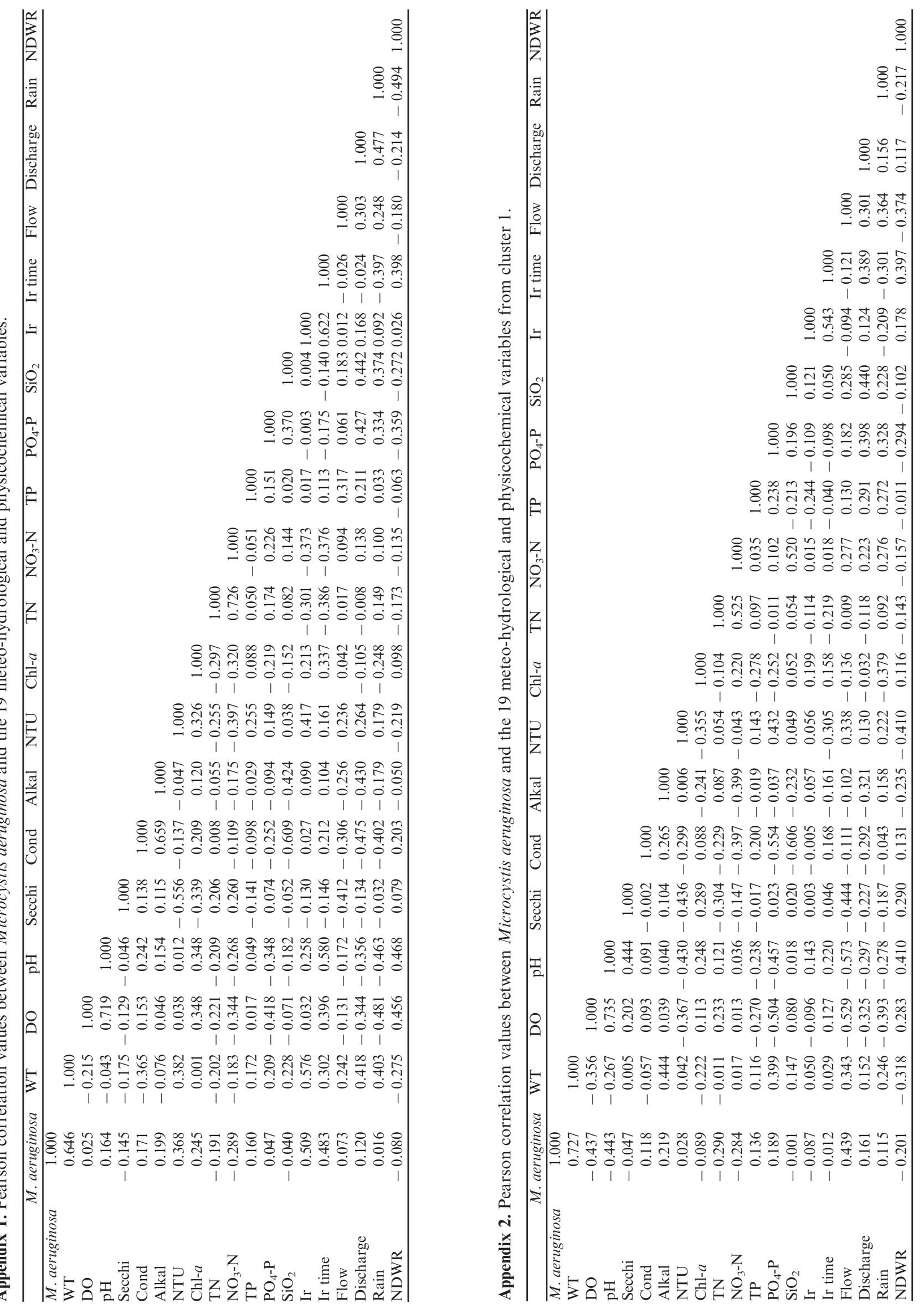

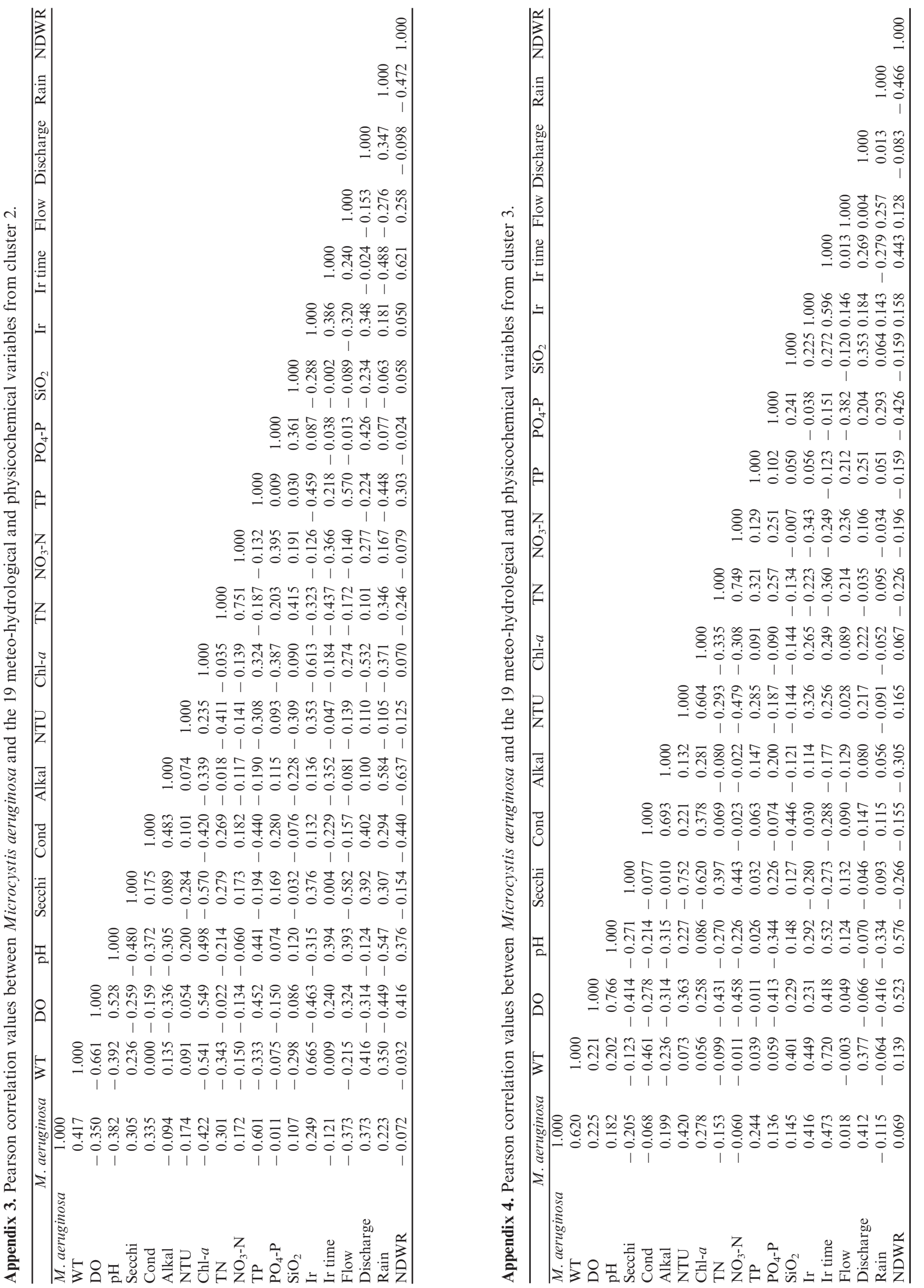